\title{
IMPROVEMENT QUALITY OF FINANCIAL STATEMENTS THROUGH APPLICATION OF GOVERMENT ACCOUNTING STANDARDS AND GOOD GOVERNANCE
}

\author{
Jafre-V2I1-02
}

\begin{abstract}
The Study aims to analyze improvement quality of financial report through application of governance accounting standards and good governance. Analyzed the data obtained by using analysis quantitative. Quantitative analysis includes multiple regression analysis, coefficient of determination analysis and hypothesis throuhh $t$ test and $\mathrm{f}$ test. The results of research and statistical analysis using shows that the quality of financial statements is influenced by the application of government accounting standards and good governance.

Keywords: Quality of Financial Statement, Government Accounting Standars, Good Governance.
\end{abstract}

\section{PENDAHULUAN}

\section{Latar belakang}

Standar akuntansi pemerintahan mengakui pendapatan, belanja, dan diatur dalam Peraturan Pemerintah pembiayaan dalam pelaporan Nomor 71 Tahun 2010. Pemerintah pelaksanaan anggaran berdasarkan menerapkan Standar Akuntansi basis yang ditetapkan dalam Pemerintahan Berbasis Akrual, yaitu APBN/APBD. Standar Akuntansi Standar Akuntansi Pemerintah yang Pemerintahan Berbasis Akrual tersebut mengakui pendapatan, beban, aset, dinyatakan dalam bentuk PSAP dan utang, dan ekuitas dalam pelaporan dilengkap dengan kerangka konseptual finansial berbasis akrual, serta akuntansi pemerintahan. 
Good governance adalah suatu penyelenggaraan manajamen pembangunan yang solid dan bertanggungjawab yang sejalan dengan prinsip demokrasi dan pasar yang efisien, penghindaran salah alokasi dana investasi dan pencegahan korupsi baik secara politik maupun administratif, menjalalankan disiplin angaran serta penciptaan legal political frame work bagi tumbuhnya aktifitas usha, Padahal, selama ini birokrasi di daerah dianggap tidak kompeten. Isu Good Governace (pemerintahan yang baik) merupakan wacana yang banyak dibicarakan saat ini mulai dari kebijakan yang diambil oleh pemerintah hingga bagaimana menjalankan kebijakan tersebut. Apakah kebijakan yang diambil pemerintah pro terhadap rakyat ataukah malah bersifat oportunis bagi sang pemangku jabatan. Semakin tingginya tuntutan masyarakat agar instansi pemerintahan menyelenggarakan prinsip-prinsip Good Governace berbanding lurus dengan meningkatnya tingkat pengetahuan dan pendidikan masyarakat.

Definisi laporan keuangan menurut Mahmudi (2010: 1) merupakan suatu bentuk pertanggungjawaban pemerintah kepada rakyat atas pengelolaan dana publik baik dari pajak, retribusi atau transaksi lainnya. Laporan keuangan merupakan suatu pernyataan entitas pelaporan yang terkandung di dalam komponen laporan keuangan. Laporan keuangan adalah bentuk pertanggungjawaban pengelolaan keuangan negara/daerah selama suatu periode. laporan keuangan pemerintah 
daerah adalah pertanggungjawaban pelaksanaan Anggaran Pendapatan Belanja Daerah. Sedangkan Mardiasmo (2004: 159) mendefinisikan laporan keuangan pada dasarnya adalah hasil dari proses akuntansi yang dapat digunakan sebagai alat untuk berkomunikasi antara data keuangan atau aktifitas suatu perusahaaan dengan pihak-pihak yang berkepentingan dengan data atau aktivitas perusahaan tersebut.

Tujuan dari penerapan Standar Akuntansi Pemerintahan ini sebagai acuan bagi penyusun laporan keuangan pemerintahan pusat dan daerah dalam melaksanakan tugasnya, penyusun laporan keuangan dalam menanggulangi masalah akuntansi yang belum diatur dalam standar, pemeriksa dalam memberikan pendapat mengenai apakah laporan keuangan disusun sesuai dengan standar akuntansi pemerintahan, dan para pengguna laporan keuangan dalam menafsirkan informasi yang disajikan pada laporan keuangan yang disusun sesuai dengan Standar Akuntansi Pemerintahan (Mursyidi, 2009).

Rancangan Peraturan Daerah tentang Perubahan Anggaran Pendapatan Belanja Daerah Kabupaten Gowa tahun anggaran 2017 diserahkan ke DPRD Kabupaten Gowa. Pembahasan kebijakan umum perubahan anggaran dan prioritas plafon anggaran perubahan tahun anggaran 2017 oleh tim anggaran pemerintah daerah bersama dengan badan anggaran DPRD Kabupaten Gowa, mencapai kesepakatan yang dituangkan dalam nota kesepakatan bersama. Bupati Gowa, Adnan 
Purichta Ichsan saat penyerahan rancangan peraturan daerah menjelaskan, terkait anggaran yang mendapatkan perubahan rancangan pendapatan daerah Kabupaten Gowa mengalami kenaikan Sebesar Rp 244.952.111.676 atau $16,03 \%$ dari anggaran pokok sebesar Rp 1.528.331.162 sehingga anggaran setelah perubahan menjadi Rp 1.773.283.273.873.

Pendapatan daerah ini dialokasikan untuk membiayai belanja tidak langsung dan belanja langsung. Untuk belanja tidak langsung mengalami kenaikan $\operatorname{Rp} 31.550 .900 .302$ naik sekitar $3.60 \%$ dari anggaran pokok sebesar Rp 877.221.727.967 menjadi Rp. 908.772.628.270. Untuk belanja langsung peningkatan sebesar Rp 279.311.383.198 mengalami penambahan sekitar $42.17 \%$, dari anggaran pokok Rp 662.320.132.475 menjadi Rp 941.631.515.674.

Dalam anggaran perubahan ini kami juga telah memasukkan integrasi BPJS yang akan mulai berlaku pada Oktober 2017. Selain itu terkait PP nomor 18 tahun 2017 terkait hak keuangan dan administratif pimpinan dan anggota DPRD. Perubahan pada anggaran ini dilakukan untuk menyesuaikan kondisi dan situasi perkembangan daerah, yang mengacu pada Rencana Kerja Pemerintah Daerah Kabupaten Gowa tahun 2017. Perubahan kami prioritaskan Satuan Kerja Perangkat Daerah yang memang mengalami pengurangan Anggaran Pendapatan Belanja Daerah Pokok 2017 serta kegiatan yang bersifat strategis dan mendesak (Pemkab Gowa). 
Penelitian ini merujuk pada tidak berpengaruh secara signifikan penelitian sebelumnya yang dilakukan terhadap peningkatan kinerja pengelolaan oleh Nurmiati, 2017 yang berjudul keuangan daerah pemerintah Kabupaten Efek Moderasi Good Governance Meningkatkan Kinerja Pengelolaan Keuangan Daerah Kabupaten Pangkep bahwa efek moderasi good governance mampu meningkatkan kinerja pengelolaan keuangan dengan variabel independen kompetensi sumber daya manusia dan teknologi informasi, walaupun jika secara langsung baik variabel kompetensi sumber daya manusia maupun teknologi informasi

\section{TINJAUAN PUSTAKA}

\section{Konsep Standar Akuntansi pemerintahan}

Salah satu upaya konkrit untuk mewujudkan transparansi dan akuntabilitas pengelolaan keuangan negara adalah penyampaian laporan pertanggung jawaban keuangan pemerintah yang memenuhi prinsip tepat waktu dan disusun dengan

mengikuti Standar Akuntansi Pemerintahan yang telah diterima secara umum. Hal tersebut diatur dalam Undang-Undang No. 17 Tahun 2003 tentang Keuangan Negara yang mensyaratkan bentuk dan isi laporan pertanggung jawaban pelaksanaan APBN/ 


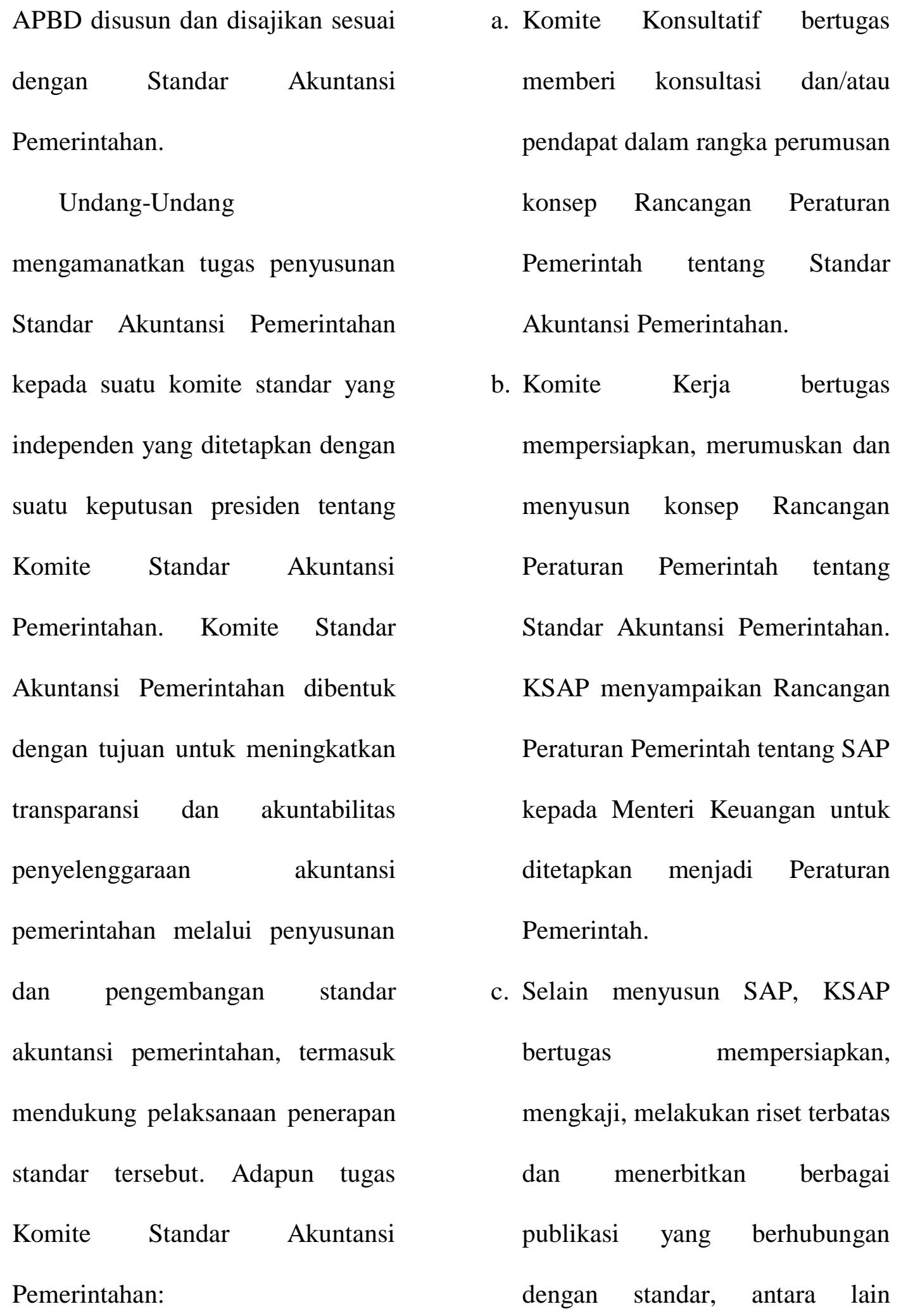




\begin{tabular}{|c|c|}
\hline Interpretasi Pernyataan Standar & laporan keuangan. Bagi auditor, \\
\hline Akuntansi Pemerintahan (IPSAP) & khususnya eksternal auditor, \\
\hline dan Buletin Teknis. IPSAP dan & digunakan sebagai \\
\hline merupakan & menilai informasi yang disajikan \\
\hline pedoman dan informasi yang & apakah sesuai \\
\hline diterbitkan oleh KSAP untuk & akuntansi berterima umum. \\
\hline memudahkan pemahaman dan & merupakan acuan wajib dalam \\
\hline penerapan SAP, serta untuk & penyajian laporan keuangan entitas \\
\hline masalah-masalah & pemerintah, baik pemerintah pusat \\
\hline akuntansi dan & dan juga pemerintah daerah wajib \\
\hline keuangan, (UU No.17, 2003, pasal & menyajikan laporan keuangan sesuai \\
\hline 32 ayat 1. Dan No. 71, 2010 ). & dengan SAP. Pengguna \\
\hline tandar akuntansi berguna bagi & keuangan termasuk legislatif akan \\
\hline yusun laporan keuangan dalam & menggunakan SAP untuk memahami \\
\hline nentukan informasi yang harus & informasi yang disajikan dalam \\
\hline sajikan kepada pihak-pihak di luar & laporan keuangan dan eksternal \\
\hline ganisasi. Para pengguna laporan & auditor (BPK) akan menggunakannya \\
\hline angan di luar organisasi akan & sebagai kriteria dalam pelaksanaan \\
\hline pat memahami informasi yang & audit. Dengan demikian SAP menjadi \\
\hline sajikan jika disajikan dengan & pedoman untuk menyatukan persepsi \\
\hline yang dipahami & antara penyusun, \\
\hline
\end{tabular}


Standar Akuntansi Pemerintahan

adalah prinsip-prinsip akuntansi yang diterapkan dalam menyusun dan menyajikan laporan keuangan pemerintah. Dengan demikian, Standar Akuntansi Pemerintahan merupakan persyaratan yang mempunyai kekuatan hukum dalam upaya meningkatkan kualitas laporan keuangan pemerintah di Indonesia. Dengan diterapkannya Standar akuntansi Pemerintahan di setiap instansi Satuan Kerja Perangkat Daerah diharapkan mampu meningkatkan kualitas laporan yang diterbitkan. Ada delapan prinsip yang digunakan dalam akuntansi dan pelaporan keuangan pemerintah:

a) Basis Akuntansi

Basis akuntansi yang digunakan dalam laporan keuangan pemerintah adalah basis akrual, untuk pengakuan pendapatan laporan operasional, beban, aset, kewajiban, dan ekuitas. Dalam hal peraturan perundangan mewajibkan disajikannya laporan keuangan dengan basis kas, maka entitas wajib menyajikan laporan demikian. Basis akrual untuk Neraca berarti bahwa aset, kewajiban, dan ekuitas diakui dan dicatat pada saat terjadinya transaksi, atau pada saat kejadian atau kondisi lingkungan berpengaruh pada keuangan pemerintah, tanpa memperhatikan saat kas atau setara kas diterima atau dibayar.

b) Nilai Historis (Historical Cost)

Aset dicatat sebesar pengeluaran kas dan setara kas yang dibayar atau sebesar nilai wajar dari imbalan (consideration) untuk memperoleh aset tersebut pada saat 
perolehan. Kewajiban dicatat

sebesar jumlah kas dan setara kas

yang diharapkan akan dibayarkan

untuk memenuhi kewajiban di

masa yang akan datang dalam

pelaksanaan kegiatan pemerintah.

Nilai historis lebih dapat

diandalkan daripada penilaian yang

lain karena lebih obyektif dan

dapat diverifikasi. Dalam hal tidak

terdapat nilai historis, dapat

digunakan nilai wajar aset atau

kewajiban terkait.

c) Realisasi (Realization)

Bagi pemerintah, pendapatan basis

kas yang tersedia yang telah

diotorisasikan melalui anggaran

pemerintah suatu periode akuntansi

akan digunakan untuk membayar

utang dan belanja dalam periode

tersebut. Mengingat Laporan

Realisasi Anggaran masih merupakan laporan yang wajib disusun, maka pendapatan atau belanja basis kas diakui setelah diotorisasi melalui anggaran dan telah menambah atau mengurangi kas.. Prinsip layak temu biayapendapatan (matching-cost against revenue principle) dalam akuntansi pemerintah tidak mendapat penekanan sebagaimana dipraktekkan dalam akuntansi komersial.

d) Substansi Mengungguli Bentuk Formal (Substance Over Form)

Informasi dimaksudkan untuk menyajikan dengan wajar transaksi serta peristiwa lain yang seharusnya disajikan, maka transaksi atau peristiwa lain tersebut perlu dicatat dan disajikan sesuai dengan substansi dan realitas ekonomi, dan bukan hanya 
aspek formalitasnya. Apabila

substansi transaksi atau peristiwa lain tidak konsisten/ berbeda dengan aspek formalitasnya, maka hal tersebut harus diungkapkan dengan jelas dalam Catatan atas Laporan Keuangan.

e) Periodisitas (Periodicity)

Kegiatan akuntansi dan pelaporan keuangan entitas pelaporan perlu dibagi menjadi periode-periode pelaporan sehingga kinerja entitas dapat diukur dan posisi sumber daya yang dimilikinya dapat ditentukan. Periode utama yang digunakan adalah tahunan. Namun, periode bulanan, triwulanan, dan semesteran juga dianjurkan.

f) Konsistensi (Consistency)

Perlakuan akuntansi yang sama diterapkan pada kejadian yang serupa dari periode ke periode oleh suatu entitas pelaporan (prinsip konsistensi internal). Hal ini tidak berarti bahwa tidak boleh terjadi perubahan dari satu metode akuntansi ke metode akuntansi yang lain. Metode akuntansi yang dipakai dapat diubah dengan syarat bahwa metode yang baru diterapkan mampu memberikan informasi yang lebih baik dibanding metode lama. Pengaruh atas perubahan penerapan metode ini diungkapkan dalam Catatan atas Laporan Keuangan.

g) Pengungkapan Lengkap (Full Disclosure)

Laporan keuangan menyajikan secara lengkap informasi yang dibutuhkan oleh pengguna. Informasi yang dibutuhkan oleh pengguna laporan keuangan dapat ditempatkan pada lembar muka (on 
the face) laporan keuangan atau

Catatan atas Laporan Keuangan.

h) Penyajian

Wajar

(Fair

Presentation)

Laporan keuangan menyajikan dengan wajar Laporan Realisasi Anggaran, Laporan Perubahan

Saldo Anggaran Lebih, Neraca, Laporan Operasional, Laporan Arus Kas, Laporan Perubahan Ekuitas, dan Catatan atas Laporan Keuangan. Dalam rangka penyajian wajar, faktor pertimbangan sehat diperlukan bagi penyusun laporan keuangan ketika menghadapi ketidakpastian peristiwa dan keadaan tertentu. Ketidakpastian seperti itu diakui dengan mengungkapkan hakikat serta tingkatnya dengan menggunakan pertimbangan sehat dalam penyusunan laporan keuangan.

\section{Konsep Good Governance}

Good governance adalah suatu penyelenggaraan manajamen pembangunan yang solid dan bertanggungjawab yang sejalan dengan prinsip demokrasi dan pasar yang efisien, penghindaran salah alokasi dana investasi dan pencegahan korupsi baik secara politik maupun administratif, menjalalankan disiplin angaran serta penciptaan legal political frame work bagi tumbuhnya aktifitas usaha, Padahal, selama ini birokrasi di daerah dianggap tidak kompeten. Isu Good Governace (pemerintahan yang baik) merupakan wacana yang banyak dibicarakan saat ini mulai dari kebijakan yang diambil oleh pemerintah hingga bagaimana menjalankan kebijakan tersebut. 
Good governance menurut Bank Dunia sebagai cara kekuasaan negara digunakan dalam mengelola sumber daya ekonomi dan sosial untuk pembangunan dan masyarakat. (Nurmiati, dkk, 2017). Semakin tingginya tuntutan masyarakat agar instansi pemerintahan menyelenggarakan prinsip-prinsip Good Governace berbanding lurus dengan meningkatnya tingkat pengetahuan dan pendidikan masyarakat. Ada tiga komponen utama Good Governace yaitu:

1) Transparansi

Instansi pemerintahan bisa dikatakan jujur ketika instansi tersebut telah menjalankan prinsip transparansi. Hal tersebut bisa terwujud dengan menampilkan laporan keuangan secara penuh tanpa menyembunyikan atau menutupi suatu kecurangan yang dilakukan instansi tersebut.

2) Partisipasi

Pemerintahan yang baik tidak boleh lepas dari unsur partisipasi masyarakat. Masyarakat memiliki peranan penting dalam setiap pengambilan keputusan. Jadi kualitas informasi akan semakin tinggi jika masyarakt di ikut sertakan untuk menilai laporan instansi pemerintah. Sehingga masyarakat juga jadi lebih tahu mengenai kinerja instansi pemerintah yang menaungi daerahnya.

3) Akuntabilitas

Akuntabilitas instansi
pemerintahan merupakan
instrumen untuk mengontrol
pencapaian instansi tersebut.
Apakah instansi yang
bersangkutan sudah mencapai


target yang di tentukan sebelumnya atau kah malah instansi tersebut tidak memiliki pencapaian selama periode masa kerjanya.

\section{Konsep Kualitas Laporan Keuangan}

Karakteristik kualitatif laporan keuangan adalah ukuran-ukuran normative yang perlu diwujudkan dalam informasi akuntansi sehingga dapat memenuhi tujuannya. Terdapat empat karakteristik kualitatif yaitu relevan, andal, dapat dibandingkan dan dapat dipahami, yang merupakan prasyarat normatif yang diperlukan agar laporan keuangan dapat memenuhi kualitas yang dikehendaki. Laporan Keuangan instansi pemerintah harus bermanfaat dan sesuai dengan kebutuhan para pemakai. Instansi pemerintah wajib memperhatikan informasi yang disajikan dalam laporan keuangan untuk keperluan perencanaan, pengendalian, dan pengambilan keputusan.

Informasi akuntansi yang terdapat di dalam laporan keuangan instansi pemerintah harus memenuhi beberapa karakteristik kualitatif yang sebagaimana disyaratkan dalam Peraturan Pemerintah No. 17 Tahun 2010 tentang Standar Akuntansi Pemerintahan, yakni:

a) Relevan

Laporan keuangan bisa
dikatakan relevan apabila
informasi yang termuat di
dalamnya dapat mempengaruhi
keputusan pengguna dengan
membantu mereka
mengevaluasi peristiwa masa
lalu atau masa kini dan
memprediksi masa depan serta
menegaskan atau mengoreksi
hasil evaluasi mereka di masa


lalu. Dengan demikian informasi laporan keuangan yang relevan dapat dihubungkan dengan maksud penggunaannya.

Informasi yang relevan :

1) Memiliki manfaat umpan balik (feedback value), Informasi memungkinkan pengguna untuk menegaskan alat mengoreksi ekspektasi mereka di masa lalu.

2) Memiliki manfaat prediktif (predictive value), Informasi dapat membantu pengguna untuk memprediksi masa yang akan datang berdasarkan hasil masa lalu dan kejadian masa kini.

3) Tepat waktu, Informasi disajikan tepat waktu sehingga dapat berpengaruh dan berguna dalam pengambilan keputusan.
4) Lengkap, Informasi akuntansi keuangan pemerintah disajikan selengkap mungkin yaitu mencakup semua informasi akuntansi yang dapat mempengaruhi pengambilan keputusan. Informasi yang melatar belakangi setiap butir informasi utama yang termuat dalam laporan keuangan diungkapkan dengan jelas agar kekeliruan dalam penggunaan informasi tersebut dapat dicegah.

b) Andal

$$
\text { Informasi Dalam laporan }
$$
keuangan bebas dari pengertian yang menyesatkan dan kesalahan material, menyajikan setiap fakta secara jujur, serta dapat diverifikasi.

Informasi mungkin relevan, tetapi jika hakikat atau 
penyajiannya tidak dapat

diandalkan maka penggunaan

informasi tersebut secara

potensial dapat menyesatkan.

Informasi yang andal

memenuhi karakteristik:

1) Penyajian Jujur, Informasi

menggambarkan dengan

jujur transaksi serta

peristiwa lainnya yang

seharusnya disajikan atau

yang secara wajar dapat

diharapkan untuk disajikan.

2) Dapat Diverifikasi

(verifiability), Informasi

yang disajikan Dalam

laporan keuangan dapat

diuji, dan apabila pengujian

dilakukan lebih dari sekali

oleh pihak yang berbeda,

hasilnya tetap menunjukkan

simpulan yang tidak

berbeda jauh.
3) Netralitas, Informasi diarahkan pada kebutuhan umum dan tidak berpihak pada kebutuhan pihak tertentu.

c) Dapat dibandingkan

Informasi yang termuat dalam laporan keuangan akan lebih berguna jika dapat dibandingkan dengan laporan keuangan periode Sebelumnya atau laporan keuangan entitas pelaporan lain pada umumnya. Perbandingan dapat dilakukan secara internal dan eksternal. Perbandingan secara internal dapat dilakukan bila suatu entitas menerapkan kebijakan akuntansi yang sama dari tahun ke tahun. Perbandingan secara eksternal dapat dilakukan bila entitas yang diperbandingkan menerapkan kebijakan akuntansi yang sama. Apabila entitas pemerintah akan 
menerapkan kebijakan akuntansi

yang lebih baik daripada

kebijakan akuntansi yang

sekarang diterapkan, perubahan

tersebut diungkapkan pada

periode terjadinya perubahan.

d) Dapat dipahami

Informasi yang disajikan

Dalam laporan keuangan dapat

dipahami oleh pengguna dan

dinyatakan dalam bentuk serta

istilah yang disesuaikan dengan

batas pemahaman para

pengguna. Untuk itu, pengguna

diasumsikan

memiliki

pengetahuan yang memadai atas

kegiatan dan lingkungan operasi

entitas pelaporan, serta adanya

kemauan pengguna untuk

mempelajari informasi yang

dimaksud.

\section{METODE PENELITIAN}

Jenis Penelitian
Apabila informasi yang terdapat di dalam Laporan Keuangan Pemerintah Daerah memenuhi kriteria karakteristik kualitatif laporan keuangan pemerintah yaitu andal, relevan, dapat dipahami dan dapat dibandingkan seperti yang disyaratkan dalam Peraturan Pemerintah Nomor 24 Tahun 2005, berarti pemerintah daerah mampu mewujudkan transparansi dan akuntabilitas dalam pengelolaan keuangan daerah. Informasi yang terkandung di dalam laporan keuangan yang dihasilkan oleh pemerintah daerah harus sesuai dengan kriteria nilai informasi yang disyaratkan oleh peraturan perundang-undangan.

Metode penelitian yang

digunakan dalam penelitian ini adalah 
metode kuantitatif eksplanasi, dimana penelitan eksplanasi adalah penelitian untuk menguji hubungan antarvariabel yang di hipotesiskan, ada hipotesis yang diuji kebenarannya. Hipotesis itu sendiri menggambarkan hubungan antara dua atau lebih variabel; untuk mengetahui apakah suatu variabel berasosiasi atau tidak dengan variabel lainnya atau apakah suatu variabel disebabkan/dipengaruhi atau tidak oleh variabel lainnya.

\section{Jenis Data}

a) Data Kualitatif, yaitu data yang diperoleh dari Instansi baik dalam bentuk informasi secara lisan maupun secara tertulis. Seperti gambaran singkat perusahaan dan struktur organisasi. b) Data Kuantitatif, yaitu data yang diperoleh dari satuan kerja perangkat daerah yang diteliti dalam bentuk angka - angka.

\section{Sumber Data}

a) Data Primer

Data yang digunakan dalam penelitian ini adalah data primer, yaitu sumber data penelitian yang diperoleh secara langsung dari sumber aslinya. Dalam hal ini data primer berupa hasil pengisian kuesioner oleh Pegawai pada Pemerintah Daerah Kabupaten Gowa.

b) Data Sekunder

Data sekunder merupakan sumber data penelitian yang secara tidak langsung melalui media perantara (diperoleh atau dicatat pihak lain) dan sifatnya saling melengkapi. Data 
sekunder diperoleh dari berbagai sumber dan digunakan untuk menunjang informasi yang di perlukan dalam kajian yang berupa sumber pustaka yang dapat mendukung penulisan penelitian serta diperoleh dari literature yang relevan dari permasalahan, sebagai dasar pemahaman terhadap obyek penelitian dan untuk menganalisisnya secara tepat.

\section{Populasi dan Sampel}

Data dalam penelitian ini diperoleh dari data primer melalui metode survei. Populasi dalam penelitian ini adalah seluruh Pegawai pada Pemerintah Daerah Kabupaten Gowa yang berjumlah sebanyak 324 orang. Penarikan sampel yang digunakan dalam penelitian ini adalah random sampling dengan mengambil
76 orang pegawai sebagai sampel dengan menyiapkan daftar pertanyaan (kuesioner).

\section{Variabel Penelitian}

Dalam penelitian ini peneliti menggunakan variabel independent dan variabel dependent, dimana variabel independen yaitu penerapan standar akuntansi pemerintah dan Good Governance sedangkan variabel dependen yaitu kualitas laporan keuangan.

\section{Analisis Data}

Analisis ini digunakan untuk menguji hipotesis yang telah diajukan dan untuk menguji pengaruh variabel independen (variabel bebas ) terhadap variabel dependen digunakan metode analisis regresi linear berganda. Menurut Sugiyono (2012:215) dengan rumus: 


$$
\hat{\mathrm{Y}}=\mathrm{a}+\mathrm{b}_{1} \mathrm{X}_{1}+\mathrm{b}_{2} \mathrm{X}_{2}+\mathrm{e}
$$

Dimana:

$\begin{array}{ll}\hat{\mathrm{Y}} & \text { : Kualitas laporan keuangan } \\ \mathrm{X}_{1} & \text { : Standar Akuntansi Pemerintahan } \\ \mathrm{X}_{2} & \text { : Good Governace } \\ a & \text { : Konstanta } \\ \mathrm{b}_{1} & \text { : slope regresi atau koefisien regresi dari } \mathrm{X}_{1} \\ \mathrm{~b}_{2} & \text { : slope regresi atau koefisien regresi dari } \mathrm{X}_{2} \\ \mathrm{e}: \text { kesalahan residual (error turn) }\end{array}$

\section{HASIL PENELITIAN DAN PEMBAHASAN}

\section{Koefisien Determinasi $\left(R^{2}\right)$}

Koefisien determinasi $\left(R^{2}\right) \quad$ menjelaskan variabel dependen. bertujuan untuk mengetahui seberapa Berikut hasil uji koefisien determinasi besar kemampuan variabel independen pada tabel berikut :

Tabel 1.

Koefisien Determinasi $\mathbf{R}^{2}$

Model Summary

\begin{tabular}{|l|r|r|r|r|}
\hline Model & $R$ & R Square & $\begin{array}{c}\text { Adjusted R } \\
\text { Square }\end{array}$ & $\begin{array}{c}\text { Std. Error of the } \\
\text { Estimate }\end{array}$ \\
\hline 1 &, $770^{\mathrm{a}}$ &, 593 &, 581 & 2,34512 \\
\hline
\end{tabular}

a. Predictors: (Constant), GoodGovernance, StandarAkuntansiPemerintahan

b. Dependent Variable: KualitasLaporanKeuangan

Sumber : output SPSS 24, 2017 
Tabel 1. Model Summary teknik pengujian hipotesis dengan kolom $R$ menunjukkan besarnya melihat pengaruh variabel secara koefisien korelasi ganda sebesar 0,770. terpisah. Pengaruh tiap variabel Kolom $R$ Square $\left(R^{2}\right)$ merupakan independen terhadap variabel koefisien determinasi yaitu sebesar dependen akan di uji secara terpisah, 0,593. Kolom Adjusted $R$ Square $\left(R^{2}\right) \quad$ dalam artian setiap variabel $\mathrm{X}$ di uji merupakan koefisien determinasi yang pengaruhnya terhadap variabel Y. dikoreksi/ disesuaikan yaitu besarnya dalam penelitian ini yang menjadi 0,581 dan koefisien ini yang variabel independen adalah Standar digunakan dalam memberikan makna Akuntansi Pemerintahan $\left(\mathrm{X}_{1}\right)$ yang bahwa penerapan Standar Akuntansi Pemerintahan dan Good Governance secara bersama-sama memberikan kontribusi terhadap kualitas laporan keuangan $58,1 \% \quad(0,581 \quad x \quad 100 \%)$ sedangkan sisanya dipengaruhi oleh variabel lain yang tidak diteliti.

\section{Uji parsial (t)}

Uji parsial atau biasa juga dikatakan uji t (t-test) merupakan 


\section{Coefficients $^{a}$}

\begin{tabular}{|l|r|r|r|r|r|}
\hline \multirow{2}{*}{ Model } & \multicolumn{2}{|c|}{$\begin{array}{c}\text { Unstandardized } \\
\text { Coefficients }\end{array}$} & $\begin{array}{c}\text { Standardized } \\
\text { Coefficients }\end{array}$ & \multirow{2}{*}{ Sig. } \\
\cline { 2 - 5 } & \multicolumn{1}{|c|}{$\mathrm{B}$} & Std. Error & \multicolumn{1}{|c|}{ Beta } & \\
\hline & 3,954 & 5,292 & &, 747 &, 457 \\
1 (Constant) &, 281 &, 060 &, 401 & 4,689 &, 000 \\
StandarAkuntansiPemerintahan &, 681 &, 114 &, 509 & 5,961 &, 000 \\
\hline
\end{tabular}

a. Dependent Variable: KualitasLaporanKeuangan

Sumber : output SPSS 24, 2017

Tabel 2 kolom Unstandardized

Coefficients dengan subkolom $B$ merupakan koefisien yang menunjukkan harga constant $a, b 1$ dan b2. Dari ketiga koefisien ini kemudian dimasukkan dalam persamaan $Y=a+b_{1} X_{1}+b_{2} X_{2}$ sehingga persamaan regresi menjadi :

$$
\mathrm{Y}=3,954+0,281 X_{1}+0,681 X_{2}
$$

Pada model regresi yang telah didapatkan dengan taksiran diatas, yaitu maka memperlihatkan bahwa taksiran itersep $a$ sebesar 3,954 dan taksiran parameter dari $b_{1}$ sebesar 0,281 dan taksiran parameter dari $b_{2}$ sebesar 0,681. Penjelasan dari persamaan tersebut dapat diuraikan sebagai berikut:

a. Konstanta $=3,954$, artinya ada atau tidaknya pengaruh penerapan Standar Akuntansi Pemerintahan dan Good governance, maka kualitas laporan keuangan tidak akan mengalami perubahan baik bertambah ataupun berkurang (tetap).

b. Koefesien regresi $X_{1}=0,281$, artinya jika penerapan Standar Akuntansi Pemerintah meningkat satu satuan, maka kualitas laporan 
keuangan akan meningkat sebesar 0,281 .

c. Koefesian regresi $X_{2}=0,681$, artinya adalah jika Good Governance meningkat satu satuan, maka kualitas laporan keuangan akan meningkat sebesar 0,681.

Penjelasan lain dari hasil persamaan tersebut dapat berarti

\section{Uji Simultan (F)}

bahwa, jika penerapan Standar Akuntansi Pemerintah bertambah satu tingkatan maka kualitas laporan keuangan rata-rata akan meningkat sebesar 0,281 dan Good Governance bertambah satu tingkatan maka kualitas laporan keuangan rata-rata akan meningkat sebesar 0,681 .

Tabel 3. Hasil Uji Simultan ANOVA $^{a}$

\begin{tabular}{|c|c|c|c|c|c|c|}
\hline \multicolumn{2}{|c|}{ Model } & Sum of Squares & $\mathrm{Df}$ & Mean Square & $\mathrm{F}$ & Sig. \\
\hline \multirow{3}{*}{1} & Regression & 544,618 & 2 & 272,309 & 49,514 &, $000^{b}$ \\
\hline & Residual & 373,974 & 68 & 5,500 & & \\
\hline & Total & 918,592 & 70 & & & \\
\hline
\end{tabular}

a. Dependent Variable: KualitasLaporanKeuangan

b. Predictors: (Constant), GoodGovernance, StandarAkuntansiPemerintahan Sumber : output SPSS 24, 2017

Tabel 3. menunjukkan hasil uji simultan. Untuk mengetahui apakah Standar Akuntansi Pemerintahan $\left(\mathrm{X}_{1}\right)$ dan Good Governance $\left(\mathrm{X}_{2}\right)$ berpengaruh secara bersama-sama terhadap kualitas laporan keuangan
(Y) dengan melakukan uji F. Apabila nilai $F_{\text {hitung }}$ lebih besar daripada nilai $\mathrm{F}_{\text {tabel }}$ maka bisa dikatakan bahwa $\mathrm{X}_{1}$ dan $\mathrm{X}_{2}$ berpengaruh secara simultan terhadap Y. Nilai $F_{\text {hitung }}$ pada tabel diatas yaitu 49,514 sedangkan nilai 
$F_{\text {tabel yaitu 3.13. Karena }} F_{\text {hitung }}>F_{\text {tabel }}$

$(49,514>3.13)$ maka disimpulkan

bahwa pengaruh Standar Akuntansi

Pemerintahan dan Good Governance

berpengaruh secara simultan atau

secara bersama-sama terhadap kualitas

laporan keuangan.

Pengaruh penerapan Standar

Akuntansi Pemerintahan (X) terhadap kualitas laporan keuangan (Y)

Hasil persamaan regresi dengan bantuan alat statistik SPSS 24, koefisien regresi untuk variabel independent yaitu Penerapan standar akuntansi pemerintahan $\left(\mathrm{X}_{1}\right)$ dilakukan pengujian keberartian dengan uji t.

Nilai $t_{\text {tabel }}$ dengan signifikansi

$5 \%$ dan nilai df $69(\mathrm{~N}-2)$ atau (71-2) adalah 1,669. Pada tabel 2 nilai $t_{\text {hitung }}$ variabel Standar Akuntansi

Pemerintahan $\left(\mathrm{X}_{1}\right)$ adalah 4,689.

Untuk variabel $X_{1}$ nilai $t_{\text {hitung }}>t_{\text {tabel }}$

$(4,689>1,669)$ maka $H_{1}$ diterima atau

dapat diinterpretasikan bahwa variabel

penerapan Standar Akuntansi

Pemerintahan $\left(\mathrm{X}_{1}\right)$ secara parsial

mempengaruhi variabel Kualitas

laporan keuangan (Y). Nilai

probabilitas yang lebih kecil dari taraf kesalahan $5 \% \quad(0,00<0,05)$ menyatakan bahwa variabel Standar Akuntansi Pemerintahan $\left(\mathrm{X}_{1}\right)$ berpengaruh secara positif dan signifikan terhadap kualitas laporan keuangan (Y).

Pemerintah Kabupaten Gowa salah satu kualitas laporan keuangan yang harus dicapai adalah masalah relevansi. Kata relevan mengacu kepada dampak dari informasi dan pengaruhnya kepada keputusan 
ekonomi pemakai laporan dengan membantu mereka mengevaluasi peristiwa masa lalu, masa kini atau masa depan, atau mengoreksi hasil evaluasi mereka dimasa lalu sehingga informasi yang relevan dapat memberikan manfaat umpan balik dan prediktif. Dengan itu setiap intansi pemerintah agar kiranya dapat menerapkan Standar Akuntansi Pemerintah yang agar laporan keuangan baik dan benar.

Diterimanya $\quad \mathrm{H}_{1} \quad$ yaitu penerapan Standar Akuntansi Pemerintahan $\left(X_{1}\right)$ berpengaruh positif dan signifikan terhadap kualitas laporan keuangan (Y) pada Satuan Kerja Perangkat Daerah di Kabupaten Gowa, hal ini memperkuat dan sejalan dengan penelitian tentang pengaruh Penerapan Standar Akuntansi Pemerintahan Terhadap Kualitas
Laporan Keuangan (Survey Pada Pemerintahan Daerah Di Jawa Barat), dari hasil penelitian memberikan bukti bahwa dengan adanya kejelasan standar akuntansi pemerintahan yang dipakai, maka akan dihasilkan laporan keuangan yang berkualitas.

Penerapan Standar Akuntansi Pemerintahan yang semakin baik maka akan dibarengi oleh kualitas laporan keuangan yang semakin baik pula, Dengan kata lain Standar Akuntansi Pemerintah akan turut meningkatkan kualitas laporan keuangan.

Pengaruh Good Governance $\left(\mathbf{X}_{2}\right)$ terhadap kualitas laporan keuangan (Y)

Hasil persamaan regresi dengan bantuan alat statistik SPSS 24 , koefisien regresi untuk variabel independent yaitu Good Governance $\left(\mathrm{X}_{2}\right)$ dilakukan pengujian keberartian dengan uji t. 
Nilai $t_{\text {tabel }}$ dengan signifikansi 5\% dan nilai df $69(\mathrm{~N}-2)$ atau (71-2) adalah 1,669. Pada tabel 2. nilai thitung variabel Good Governance $\left(\mathrm{X}_{2}\right)$ adalah 5,961. Untuk variabel $\mathrm{X}_{2}$ nilai $\mathrm{t}_{\text {hitung }}>$ $\mathrm{t}_{\text {tabel }}(5,961>1,669)$ maka $\mathrm{H}_{2}$ diterima atau dapat diinterpretasikan bahwa variabel Good Governace $\left(\mathrm{X}_{2}\right)$ secara parsial mempengaruhi variabel Kualitas laporan keuangan (Y). Nilai probabilitas yang lebih kecil dari taraf kesalahan $5 \% \quad(0,00<0,05)$ menyatakan bahwa variabel Good Governance $\left(\mathrm{X}_{2}\right)$ berpengaruh secara positif dan signifikan terhadap kualitas laporan keuangan (Y).

Variabel good governance telah memberikan pengaruh yang besar terhadap kualitas laporan keuangan di setiap instansi. Hal ini menunjukan Good Governance harus dilaksanakan sesuai dengan prinsip-prinsip yang berlaku sebab sangat berpengaruh terhadap kualitas laporan keuangan. Diterimanya $\mathrm{H}_{2}$ yaitu Good Governance $\left(\mathrm{X}_{2}\right)$ berpengaruh positif dan signifikan terhadap kualitas laporan keuangan (Y) pada Satuan Kerja Perangkat Daerah di Kabupaten Gowa, ini menguatkan dan sejalan dengan penelitian sebelumnya, dalam penelitiannya menyatakan ada pengaruh variabel Good Governance terhadap kualitas laporan keuangan, dengan berdasarkan Hasil uji F nilai F sebesar 10,507 dengan signifikansi sebesar 0,000 atau lebih kecil dari taraf signifikan 0,05. Dengan demikian dapat disimpulkan bahwa Variabel Penerapan Standar Akuntansi Pemerintahan, variabel kualitas aparatur pemerintahan dan good governance secara bersama - sama 
berpengaruh terhadap Kualitas Laporan Keuangan.

Pengaruh penerapan Standar Akuntansi Pemerintahan $\left(\mathbf{X}_{1}\right)$ dan Good Governance $\left(\mathrm{X}_{2}\right)$ terhadap kualitas laporan keuangan (Y)

Hasil uji simultan Pada tabel 3 dengan bantuan alat statistik SPSS 24, koefisien regresi untuk variabel independent yaitu Standar Akuntansi Pemerintahan (X1) dan Good Governance (X2) dilakukan pengujian terhadap kualitas laporan keuangan.

Nilai Ftabel dengan signifikansi $5 \%$ dan nilai df untuk responden sebanyak 71 adalah 3,13 . Pada tabel 4.22 nilai Fhitung Standar Akuntansi Pemerintahan (X1) dan variabel Good Governance (X2) adalah 49,514. Karena Fhitung > Ftabel (49,514> 3,13) maka H0 ditolak. Nilai probabilitas yang lebih kecil dari taraf kesalahan 5\% $\quad(0,00<$ 0,05) menyatakan bahwa Standar Akuntansi Pemerintahan (X1) dan variabel Good Governance (X2) berpengaruh secara positif dan signifikan terhadap kualitas laporan keuangan (Y) secara bersama-sama hasil ini berbanding terbalik dengan hipotesa yang diajukan oleh peneliti.

Pemerintah Daerah setiap daerah harus menggunakan dan menerapakan standar akuntansi pemerintah dan Good Governance agar dapat menghasilkan laporan keuangan yang baik dan benar. Di setiap Satuan Kerja Perangkat Daerah tersebut mengelola dana terpisah untuk menatausahakan dana Anggaran Pendapatan Belanja Daerah yang dikelola oleh masing-masing Satuan Kerja Perangkat Daerah sebagai entitas akuntansi, pada Sekretariat, Dinas, dan Badan (Lembaga Teknis) telah dibentuk Satuan Kerja Perangkat Daerah yang mempunyai tugas sebagai berikut :

1. Mengakuntansikan semua transaksi yang terjadi pada Satuan Kerja 
Perangkat Daerah-nya masing- (Y) secara simultan atau bersama-sama masing.

pada Satuan Kerja Perangkat Daerah

2. Menyusun Laporan Keuangan

di Kabupaten Gowa, hal ini dapat

Satuan Kerja Perangkat Daerah baik

dilihat dari nilai $t_{\text {hitung yang lebih besar }}$

laporan Semester maupun untuk dari nilai $t_{\text {tabel. }}$ Artinya bahwa hipotesis

Laporan Akhir Tahun.

yang di ajukan oleh peneliti tidak

Dalam penelitian ini sejalan dengan hasil penelitian yang terdapatnya perbedaan hasil uji SPSS dengan hipotesa yang diajukan oleh peneliti yang dimana hasil uji SPSS diterimanya $\mathrm{H}_{\mathrm{o}}$ yaitu penerapan Standar Akuntansi Pemerintahan $\left(\mathrm{X}_{1}\right)$ dan Good Governance $\left(\mathrm{X}_{2}\right)$ berpengaruh positif dan signifikan terhadap kualitas laporan keuangan

\section{KESIMPULAN DAN SARAN}

\section{Kesimpulan}

menerapkan Standar Akuntansi

1. Penerapan Standar Akuntansi

pemerintahan akan sangat pemerintahan $\mathrm{X}_{1}$ secara parsial menunjang kualitas laporan mempengaruhi variabel kualitas keuangan yang disajikan dalam laporan keuangan Y. Hal ini rangka menggambarkan keadaan menunjukkan ketaatan dalam sebenarnya dari sebuah instansi. 
2. Good Governance $X_{2}$ secara parsial mempengaruhi variabel kualitas laporan keuangan Y. Hal ini mengindikasikan bahwa penerapan prinsip prinsip Good Governance akan mempengaruhi tingkat kualitas laporan keuangan. Sehingga para pengguna laporan keuangan tidak tersesat oleh informasi salah yang disajikan.

3. Penerapan Standar Akuntansi pemerintahan $\left(\mathrm{X}_{1}\right)$ dan Good Saran

Para pengguna anggaran dan para pengguna barang pada masingmasing Satuan Kerja Perangkat Daerah diharapkan dalam membuat laporan keuangan menjunjung tinggi prinsip prinsip Standar Akuntansi Pemerintahan sehingga laporan yang

\section{DAFTAR PUSTAKA}

Irvan, N., Mus, A. R., Su'un, M., \& Sufri, M. (2017). Effect of
Governance $\left(\mathrm{X}_{2}\right)$ tidak secara bersama-sama mempengaruhi variabel kualitas laporan keuangan Y, hipotesa yang dilakukan oleh peneliti berbeda dengan hasil dari uji SPSS yang dimana kualitas laporan keuangan akan semakin baik jika kedua variabel $\mathrm{X}_{1}$ dan $\left(\mathrm{X}_{2}\right)$ diterapkan bersama sama di Satuan Kerja Perangkat Daerah Kabupaten Gowa.

dibuat memiliki kualitas di mata pengguna informasi. Satuan Kerja Perangkat Daerah diharapkan dalam membuat laporan keuangan agar menerapkan prinsip Good Governance sehingga laporan keuangan yang disajikan bebas dari rekayasa untuk menutupi kecurangan pihak tertentu.

Human Resource Competencies, Information Technology and 
Internal Control Systems on Good Governance and Local Government Financial Management Performance.

Mahmudi. (2012). Analisis Laporan Keuangan Pemerintah Daerah. Yogyakarta: UPP STIM YKPN.

Mardiasmo. (2002). Akuntansi Sektor Publik. Yoyakarta: Andi Offiset.

Mursyidi. (2009). Akuntansi Pemerintahan di Indonesia. Bandung: Refika Aditama. Retrieved from https://catalogue.nla.gov.au/Recor d/4585043

Nurlan, D. (2008). Akuntansi Keuangan Daerah. Jakarta: Indeks.

Nurmiati, N. (2017). Efek Moderasi Good Governance Meningkatkan Kinerja Pengelolaan Keuangan Daerah Kabupaten Pangkep. In Assets (Vol. 7, pp. 230-245).

Peraturan Pemerintah Nomor 71 Tahun 2010 Tentang Standar Akuntansi Pemerintahan.
Santoso, U., \& Pambelum, Y. J. (2008). Pengaruh Penerapan Akuntansi Sektor Publik Terhadap Akuntabilitas Kinerja Instansi Pemerintah Dalam Mencegah Fraud. Jurnal Administrasi Bisnis, 4(1).

Sugiyono. (2008). Metode Penelitian Kuantitatif kualitatif dan R\&D. Bandung: Alfabeta, 124.

Undang-Undang Nomor 17 Tahun 2003 Tentang Keuangan Negara.

Zeyn, E. (2011). Pengaruh good governance dan standar akuntansi pemerintahan terhadap akuntabilitas keuangan dengan komitmen organisasi sebagai pemoderasi. Jurnal Reviu Akuntansi Dan Keuangan, 1(1), 21-36. 